\title{
Leadership And Human Resource Development
}

\author{
Dr. Ololo Kennedy Okechukwu \\ Department Of Sociologyfederal University Ndufu Alike IkwoAbakalike Ebonyi Stategsm
}

\begin{abstract}
The paper focuses on leadership and human resources development with particular reference to Nigeria Apex Bank. The study objective is to determine the relationship between leadership style and human resource development as well as the attainment of organizational goals. The methodology implied in this study is systematic random sampling technique. Three branches of CBN was purposely selected i.e. Abuja, Lagos and Enugu. 180 questionnaires were distributed and 150 were filled and returned. The study observes that there are significant relationships between leadership styles and human resource development as well as staff performances and attainment of organizational goals. The study however recommends that for organizations to thrive in this globalized and competitive society, there is need to develop a leadership style that is strongly oriented to the subordinates, relying on training and retraining of human resources for effective and efficient performance towards the achievement of stated goals.
\end{abstract}

Key words: Leadership, Development, Human resources, Society, Efficient.

\section{Introduction}

Leadership entails a complex process by which a person influences others to accomplish a mission, task or objective and directs the organization in a way that makes it more cohesive and coherent. Where-ever we find an efficient and effective management system, we are almost certain to find an effective leader. What is the implication of this to human resource development? To lead is to guide, conduct, direct and proceed (Nzotta, 2010). Leaders act to help the development of human resources in organization towards attainment of organizational goals. According to Koontz et al (1984) they do not stand behind a group to push and prod, they place themselves before the group in order to facilitate progress and inspire the group to accomplish organizational goals. The implication is that the type of leader and his style of leadership will go a long way in influencing the human resources development in organization. It is against this background that this study examines the leadership and human source development in Nigerian Apex Bank.

\section{CONCEPTUAL CLARIFICATION}

Leadership is defined as the influence, the art or process of influencing people so that they will strive willingly and enthusiastically towards the achievement of group goals.Human resources could be any human effort that improve, create or add value to other factors of production. Human resources also consist of the persons and individuals who do physical and mental work.

\section{OBJECTIVES OF THE STUDY}

The study centred on the following objectives:

1 .To examine the impact of leadership style on the development of human resources,

2. To analyze the relationship between 1 leadership and development of human resources.

3. To recommend appropriate leadership style that will impact positively on human resource development in organizations.

\section{LITERATURE REVIEW}

Leaders create an environment in which the worker performs his tasks and assignment effectively. Nzotta (2010) and Flippo (1980) contend that effective environment for performance evidence show that workers tend to follow those who they perceive as providing a means of achieving their own desire, wants and needs and avenues for attaining group goal. (Robbing, 2005).

Akerele (1985), Flippo (1980) and Nzotta (2010) outlined four distinct elements of leadership;

(1) In the first instance, there must exist clearly defined authority/power of the leader, and the method of exercising this authority will determine the effectiveness of the leader. Leaders without authority and power are usually very ineffective.

(2) There must also exist an ability to comprehend that human beings have different motivating forces at varying times and in different situations. 
(3) There must be an ability to act in a way that will develop a climate for responding to and arousing motivations.

(4) The style of the leader is also important and a dispensable ingredient in leadership. Every leader must be identified with a particular style of leadership. When a style of leadership is applied in an organization, it will affect the development of human resources, positively or negatively.

\section{$\mathrm{V}$ PRINCIPLES OF LEADERSHIP}

Bariden (2002), Nzotta (2010) and Robins and Judge (2007) have identified five basic principles of leadership which are discernable towards enhancement of human resources development in organizations. These principles entail that:People generally go only where their leaders lead or allow them to go. This fact is basically true in all situations. The subordinates will move in the direction the leader leads or allows them to go. In the organizations, the leaders chart the course and direction which the followers thread. The vision of the leader, in this instance becomes the guiding light for the followers.Good leaders will take their followers as far as they themselves are able and willing to go. We are aware that leaders cannot take their followers beyond their on capabilities. This is important principles which held's time in all situations. They improve their performances through proper trainings and acquiring the right experiences. This call for leadership development.

Leaders must acquire the right training and must also show willingness to lead. Most leaders have great potentials and abilities but are not willing to put forth the effort and sacrifices which good leadership demands. Willingness can be developed according to Wiweharuck (1988) through getting involved in action, making time to understand the need of and results from a particular action, total dedication to a cause, definite priororities in one's life, discipline and deliberately staying with the task until it is completed. This calls for perseverance and patience from the leader.

Good leadership ensures that people reach their maximum potentials and go beyond their personal limitations. Good leaders must be aware of their personal limitations and make effort to reduce their effects. The essence is to remove the constraining effect of these on the organizational performance and human resource development. A leader usually is not evaluated on the basis of his personal achievement but on what his subordinates are able to accomplish under his leadership. Good leadership makes things move or happen. When there is a high level of activity or productivity, there is a form of good leadership in place or at the forefront. Good leaders are usually behind any good performance, planning, directing, coordinating and controlling in a predetermined manner. Similarly, the qualities of leadership determine the quality of the group performance. When the quality of the leadership is high the average performance of the group will be high. Good leaders demand high level of performance from the group.

\section{LEADERSHIP STYLES}

Leadership performance depends as much on the organization as it depends on the leader's attributes. Usually, we cannot speak of an effective leader or an ineffective leader. We only speak of a leader who tends to be effective in one situation and ineffective in another. Thus, effective leadership style depends on the situation. The leadership style could be based on the use of authority. This is demonstrated as autocratic leader, democratic or participative leader and leadership of free rein (Iheriohamma, 2003 and Nzotta, 2010).

Autocratic leader: - This is the leader who commands and expects compliance, who is dogmatic and positive, who leads by ability to withhold or give reward and punishment.Democratic or participative leaders: - This type of a leader tends to consult with subordinates participation by the subordinate.

Leadership of free rein: - This type of leader uses his or her power very little, if at all. The leader grants subordinate a high degree of independence or free rein in their operations. He depends on subordinates to set their own goals and also the means of achieving these goals. He perceives his role as that of facilitating the operations of followers by furnishing them with information and act as a contact with the groups' external environment and a motivator.However, for effective human resource development in an organization, state or nation, there must be prevalence of democratic or participative leadership style.

\section{THEORETICAL UNDERSTANDING}

There are various theories that explain leadership. These theories could be classified as

- Personality/unique characteristics theories.

- Behavioural theories and

- Contingency theories.

However, the study utilized contingency theory in its theoretical analysis.

The contingency theories seek to explain leadership based on the occurrence of various contingencies. Here, there is the acceptance that leadership is strongly affected by the situation from which the leader emerges and in which he operates. The contingency theory tends to focus attention on the study of situations and the belief that leaders are the products of these given situations. This approach further states that there exists an interaction 
between the human resource development and the leader. This approach further posits that the tasks being performed, the type of technology and size of the project have a close relationship with the leadership style. The situational factors include the group norms, span of control, external threats, stress and organizational culture.

When these situational factors are properly handled by the leadership at the hem of affairs, it will enhance effective human resource development.

\section{METHODOLOGY}

The study was carried out in Nigerian Apex Bank. A multistage random sampling technique was employed in data collection. Three branches of the country's Apex Bank were purposively selected, because they represent the South-East zone (Enugu), North-central (Abuja) and South - West (Lagos). From each branch sixty staff were randomly selected making a total of one hundred and fifty (180) respondents. Data were collected with the use of structured questionnaire. A total of 150 questionnaires were filled and returned.Data were analyzed with the use of descriptive statistical tools. Descriptive statistics was used to analyze the demographic characteristics of the respondents while Correlation coefficient was used to test the significant relationship between leadership style and development of human resources in Nigerian Apex Bank.

Table 1: Socio-economic characteristics of respondents

\begin{tabular}{|l|l|l|}
\hline VARIABLE & FREQUENCY & PERCENTAGE \\
\hline Sex & & \\
\hline Male & 97 & 64.70 \\
\hline Female & 58 & 35.30 \\
\hline Age & & \\
\hline $21-30$ & 25 & 16.67 \\
\hline $31-40$ & 51 & 34.00 \\
\hline $41-50$ & 42 & 28.00 \\
\hline $51-60$ & 22 & 14.67 \\
\hline 61 and Above & 10 & 6.67 \\
\hline Marital Status & \multicolumn{2}{|l|}{} \\
\hline Single & 30 & 20.00 \\
\hline Married & 101 & 67.33 \\
\hline Widowed & 12 & 8.00 \\
\hline Separated & 7 & 4.67 \\
\hline Educational Qualification & 10 & 6.67 \\
\hline FSLC & 18 & 12.00 \\
\hline SSCE & 20 & 13.33 \\
\hline OND/NCE & 68 & 45.33 \\
\hline B.SC/ANG & 34 & 22.67 \\
\hline Postgraduate Degree &
\end{tabular}

Field work Survey, January, 2014.

TABLE 2: Leadership style that develop human resources

\begin{tabular}{|l|l|l|}
\hline Leadership Style & $\begin{array}{l}\text { Number } \\
\text { Respondents }\end{array}$ & Percentage \\
\hline Autocratic & 16 & 10.67 \\
\hline Democratic & 121 & 80.67 \\
\hline Laize-faire & 13 & 8.66 \\
\hline Total & 150 & 100.00 \\
\hline
\end{tabular}

Field work Survey, January, 2014.

TABLE 3. Analysis of Relationship between leadership and development of human resources.

\begin{tabular}{|l|l|l|}
\hline Characteristics & r-value & Decision \\
\hline Staffing & 0.218 & Significant \\
\hline Performance appraisals & 0.216 & Significant \\
\hline Compensative and benefits & 0.175 & Significant \\
\hline Training and development & 0.248 & Significant \\
\hline $\begin{array}{l}\text { Employee and labour } \\
\text { relations }\end{array}$ & 0.218 & Significant \\
\hline Safety and health & 0.216 & Significant \\
\hline
\end{tabular}

Significant at 0.05 level.

TABLE 4: Empirical result of binary logistic regression model.

\begin{tabular}{|l|l|l|l|}
\hline Variable & $\begin{array}{l}\text { Logic } \\
\text { coefficient }\end{array}$ & Standard error & $\begin{array}{l}\text { Wald } \\
\text { statistic }\end{array}$ \\
\hline Constant & 15.034 & 4.45 & $6.634^{*}$ \\
\hline Staffing & 3.654 & 2.014 & $4.324^{*}$ \\
\hline Performance appraisal & 3.832 & 2.16 & $3.613^{*}$ \\
\hline
\end{tabular}




\begin{tabular}{|l|l|l|l|}
\hline Compensation \& benefits & 1.685 & 0.232 & $3.126^{*}$ \\
\hline Training and development & 3.654 & 2.014 & $4.324^{*}$ \\
\hline $\begin{array}{l}\text { Employee, and labour } \\
\text { relations }\end{array}$ & 3.654 & 2.014 & $4.324^{*}$ \\
\hline Safety and health & 2.16 & 2.16 & $3.613^{*}$ \\
\hline & Model Chi-Square 58.895 \\
$\mathrm{R}^{2}=0.898$ \\
Significant at 0.05 level.
\end{tabular}

\section{RESULTS AND DISCUSSIONS}

\section{Demographic Characteristics of Respondents}

Table 1 shows that $64.70 \%$ of the respondents by sex were males, while $35.30 \%$ were females. This shows that majority of the respondents were males, hence, males opinion will obviously dominate the responses. The table also show that $16.67 \%$ of the respondents were between the age bracket of $21-30 \mathrm{yrs}, 40.67 \%$ of the respondents were between $31-40$ years old, $30 \%$ were between the age bracket of $41-50$ years old, $12.67 \%$ of the respondents were between the age bracket $51-60$ years old. This shows that majority of the respondents were within the age bracket of $31-40$ years. This implies that majority of the respondent are still within their productive age.

Table 1 also shows that $20.00 \%$ of the respondents were single, $67.33 \%$ were married $8.00 \%$ were widowed while $4.67 \%$ of the respondents were separated. This shows that majority of the respondents were married and responsible males and females.The table further shows that $6.67 \%$ of the respondents had FSLC, $12.00 \%$ had SSCE, $13.33 \%$ had OND/NCE, $45.33 \%$ had B.Sc/HND and $22.67 \%$ of the respondents had Postgraduate degree. This shows that majority of the respondents had first degree/ HND. This implies that they can easily adapt to any leadership style in the organization.

Table 2 shows that only $10.67 \%$ of the respondents agreed that autocratic leadership style develops human resources, $80.67 \%$ supports democratic leadership, while $8.66 \%$ of the respondents agreed that Laizefaire leadership style promote human resources. This shows that majority of the staff in this organization agreed that democratic leadership enhances human resources, which supports Nzotta (2010) and Caplow (2003).

Furthermore, the test correlation as presented in table 3 shows that staffing $(r=0.218)$, performance appraisals $(\mathrm{r}=0.216)$, compensation $(\mathrm{r}=0.176)$, training and development $(\mathrm{r}=0.248)$, employee and labour relations $(\mathrm{r}=$ $0.218)$ and safety and health $(r=0.216)$ are significantly related with leadership style in Nigerian Apex bank.

The result of logistic regression analysis presented in table 4 shows that effective staffing, performance appraisal of staff, valuable compensation and benefit, staffing training and development, cordial employees and labour relations as well asemployees' health and safety are significant factors that develop through democratic leadership style being exhibited by managers in Nigerian Apex bank. The result shows that 59.00 is significant at 0.05 level, this means, that staffing, performance appraisal, compensation and benefits, training and development, employees and labour relations and safety and health show $95 \%$ confident that the presence of independent variable (democratic leadership style) contributes significantly to the development of human resources in this organization. The test also reveals that $\mathrm{R}^{2}=0.898$, which shows that about $98 \%$ of the variation in the probability of the development in the above human resources variable are determined by good leadership style using logistic regression method. The implication of the result is that, there shall not be effective staffing method, result oriented performance appraisal, valued compensation and benefits, without democratic leadership style. Also, training and development of staff are functions of good leadership in the organization. He initiates and coordinate the training and development programme in the organization.Similarly, it is only good leaders in the organization that will champion the course of cordial employees and labour relations as well as employees' safety and health.

\section{CONCLUSION}

Based on the findings, it could be concluded that coordinated democratic leadership style in this organization has affected positively towards the development of its human resources. Leadership style in Nigerian Apex bank is standardized as well as meeting the international best practice, hence the over-all human resource development being exhibited by the employees of this organization

\section{RECOMMENDATION:}

Based on the findings of this study, the following recommendations are proffered:

(1) Leadership in organizations and in Nigeria at large should endeavour to carry its followers along, through exhibition of democratic leadership principle where people's opinions should be respected.

(2) Leaders should lead by examples if they desire effective and loyal followership.

(3) Good leadership should ensure that people reach their maximum potentials and go beyond their personal limitations. 
(4) Good leadership must be aware of their personal limitations and make efforts to reduce the effects. The effective leader is to remove the constraining effects of these on the organizational performance as well as on the society at large.

(5) Leaders should endeavour to exercise their authority effectively without compromise, this will go a-long way to bring orderliness in the country.

\section{REFERENCES:}

[1]. Akerele, J.U. (1980). Management: an over view, Ibadan: Winners press limited.

[2]. Baridam, D.M. (2002). Management and organization theory,Port Harcourt: Sherbrooke Associates.

[3]. Blake, R.R. and Monton, J.S. (1981). The versitile manager: A Grid Profile,

[4]. Home Wood, Illinois: Richard D. Inwin. Inc.

[5]. Borrow, J.C. (1977). The Variables of leadership: A Review and conceptual

[6]. framework; Academy of Management Review, April 1977 pp.231 - 251.

[7]. Braiden, T.S. (2002). Organizational leadership, London :University press.

[8]. Flippo. S.D. (1980). Leadership in the organization, London :University press.

[9]. Iheriohanma, E.B. (2002). Contemporary issues in organizational theory and

[10]. management, Owerri: Grend Publishers.

[11]. Judge, A. E. (2007). Organizational behaviour, Lagos: Apex publishers.

[12]. Koontz, H; Daniel, C. and Wehrich H. (1984). Management

[13]. Tokyo: McGraw - Hill book company.

[14]. Nzotta, S.M. (2010). Human resource management:

[15]. A conceptual framework, Owerri: Good Danis Associate Press.

[16]. Robbins, S.P. and Judge, T.A. (2007).Organizational behaviour, New Jersey:

[17]. Prentice - Hall Inc. 